\author{
Federal Reserve Bank of Dallas \\ Globalization and Monetary Policy Institute \\ Working Paper No. 54 \\ http://www.dallasfed.org/assets/documents/institute/wpapers/2010/0054.pdf
}

\title{
Some Alternative Perspectives on Macroeconomic Theory and Some Policy Implications*
}

\author{
William R. White
}

July 2010

\begin{abstract}
The macroeconomic theories and models favoured by academics, as well as those used more commonly by policymakers, effectively rule out by assumption economic and financial crises of the sort we are living through. In particular, the longer run dangers posed by the rapid expansion of credit and resulting private sector balance sheet developments were inadequately appreciated. As a result, the current crisis was neither anticipated nor prepared for, and the crisis was also less well managed than it might have been. At the level of macroeconomic theory and modelling, this experience suggests that basic Keynesian insights need to be complemented by some insights from the Austrian school as well as those of Minsky. Demand factors are important, but so too are supply side and financial considerations. Such a synthesis provides a reasonable explanation of the crisis and points to some of the difficulties likely to be faced in emerging from it. As for the policy implications in current circumstances, it needs to be better recognized that policies with positive short run effects can have negative effects over a longer time period. If, as a result, fiscal and monetary expansion have now reached their limits in some countries, supply side policies must be given greater emphasis. These would include measures to encourage investment, both private and public, as well as other structural measures to raise the potential growth rate of the economy. Such measures, along with more decisive efforts to reduce the "headwinds" of over indebtedness, should with time provide the foundations for a sustainable economic recovery.
\end{abstract}

JEL codes: E32, E44

\footnotetext{
* William R White is currently the chairman of the Economic Development and Review Committee at the OECD in Paris. He was previously Economic Advisor and Head of the Monetary and Economic Department at the Bank for International Settlements in Basel, Switzerland. +41 (0) 798349066 . white.william@sunrise.ch. An initial version of this paper was presented at a meeting of the Euro50 group in Paris on 20 November, 2009. It subsequently benefitted from comments by David Laidler and Axel Leijonhufvud, neither of whom necessarily agree with all of its contents. A much altered version was presented on 27 May as the Maekawa Lecture at the 2010 International Conference of the Institute for Monetary and Economic Studies, which was held at the Bank of Japan. The views in this paper are those of the author and do not necessarily reflect the views of the Federal Reserve Bank of Dallas or the Federal Reserve System.
} 


\section{Introduction}

Everyone is painfully aware that we have just gone through a major economic and financial crisis which touched all parts of the global economy. Output levels fell sharply and unemployment and poverty rose commensurately. Many financial markets became dysfunctional and important financial institutions had to be merged or recapitalized by governments. Nor is it at all clear that the current "green shoots" of recovery will not be followed by yet another serious downturn. And the fact that an unprecedented easing of monetary and fiscal stimulus had less than expected effects on growth in some countries raises question about the effectiveness of macroeconomic policies looking forward. Against this background, one piece of good news is that the crisis has prompted some economists to rethink what they believe about how the economy works. Hopefully, such reflections will eventually lead to improvements in both macroeconomic analysis and policy prescriptions.

In the midst of the crisis, while visiting the London School of Economics, Queen Elizabeth II asked why the economics profession had failed to see it coming. In fact, most economists did not forecast the coming turbulence. This set includes virtually all academic economists, those presenting the official views of the IMF and OECD, and those representing most national governments. For the record, however, a few did give advance warnings. They told "stories" about what they felt was going wrong, based on insights mostly drawn from pre War Il economists. The more interesting question is why no one, including policymakers, was inclined to take those warnings seriously.

Perhaps the most fundamental reason was that, in the run up to the crisis, many private sector people (particularly those in the financial markets) were making huge sums of money. They were more inclined to attribute this to cleverness than to sharp increases in risk taking. In the public sector, and particularly in central banking circles, there was a wide spread conviction that, with inflation under control, nothing could go seriously wrong in the global economy. Underlying both sets of beliefs seemed to be something in human nature that says "Never look a gift horse in the mouth". Another, albeit less important, reason was the repeated assertion that we had entered permanently a "New Era" of "Great Moderation". This gave further support to the inherent optimism.

But a third reason, the subject of this lecture, is that the prevailing macroeconomic frameworks simply allowed no room for crises of the sort we are currently experiencing. As Keynes once pointed out, this framework question is fundamental.

"The ideas of economists and political philosophers, both when they are right and when they are wrong, are more powerful than is commonly understood. Indeed, the world is ruled by little else." 1

\footnotetext{
${ }^{1}$ Keynes J M (1936) p 383
} 
Absent an analytical framework which included the possibility of crises and deep economic slumps, it is not surprising that the crisis was not commonly anticipated. Nor is it surprising that no policy efforts were made to prevent the crisis from happening. Moreover, absent any fears of crisis, few ex ante preparations were made to help improve crisis management (eg adequate deposit insurance, special legislation for the insolvency of financial institutions, etc.). Further, ex post crisis management was also inadequate in that each stage of the downturn was treated as the last, and recovery was constantly said to be imminent. By way of example, problems in the banking sector were initially treated as having to do with liquidity rather than solvency, and it was generally assumed that traditional Keynesian policy responses would suffice to restore full employment.

Finally with respect to recent crisis management, there has been inadequate appreciation to date of the extent to which our policies have created a form of "moral hazard". All of the policies implemented over the last few years, however desirable in the near term, have significant down sides over a longer term horizon. Not only do they make future problems both more likely and more serious, but they also reduce the effectiveness of similar policies that might become required in the future. In fact, recent policy measures only extend further an almost continuous expansion of the public safety net over the last two decades at least ${ }^{2}$. Evidently, the concept of a series of "bubbles", reflecting in part the actions of policymakers themselves, is not easy to model in any formal fashion. Perhaps as a result, such concepts are not part of mainstream thinking about policy issues.

Evidently, simply improving our analytical frameworks will not be sufficient to avoid future crises. Nevertheless, such a reevaluation is necessary. There are many dead ends from which to escape, but there are also many promising strands of thought yet to be pursued.

It will be contended in this paper that the two workhorses of post World War II macroeconomics have serious practical deficiencies. These workhorses are referred to here as Modern Macroeconomics (made up of the New Classical and New Keynesian models favored by academics) and Applied Keynesian Models ( generally empirically estimated IS/LM models of the type still favored by policymakers and other applied economists). The former models rule out crises and deep slumps by assumption. The latter set of models underestimate the contributions made to deep slumps by developments occurring in the upswing. Thus, they overestimate the capacity of Keynesian policies to moderate deep slumps when they do occur ${ }^{3}$. In effect, they also rule out deep slumps, but on the basis of the assumption that policy will always work effectively to moderate them. Taken together,

\footnotetext{
${ }^{2}$ White W R (2004)

${ }^{3}$ As a corollary, it also implies an overestimation of the importance of policy error (ex post) in explaining deep slumps like the Great Depression or the Japanese Great Recession of the 1990's.
} 
these points also imply a greater need to lean against the upswings of credit cycles rather than to simply try to clean up afterwards ${ }^{4}$.

To remedy these deficiencies, it will be argued here that a new analytical synthesis is required. The building blocks of such a synthesis would be an increased focus on credit, stocks rather than flows (balance sheets), the possibility of stock "imbalances" (in particular excessive levels of debt), and the process of transition into crisis. In effect, the work of Keynes needs to be complemented by additional insights from the Austrian School of Economics, and still others from the work of Hyman Minsky. An increased emphasis on credit and the evolving balance sheets of both corporations and households would embellish our understanding of the demand side of the economy, both in the upswing and the downswing. Certain Austrian insights (recognizing in particular the importance of stocks of physical capital) would do the same for the supply side. The writings of Minsky are also important in that they draw attention to the implications of a complex financial system (experiencing both credit risk and liquidity risk) for the functioning of the economy as a whole.

As described, this synthesis might seem little more than a call for an improved understanding of each of the IS, AS and LM functions in standard Keynesian models. However, what is also required is a greater understanding of the dynamics of economies that eventually culminate in their being seriously out of equilibrium ${ }^{5}$. The current crisis, as well as many others in history ${ }^{6}$, indicates that economies can be far from self- equilibrating, both on the up-side and the down-side. Of particular importance today, forces can arise that reinforce the disequilibrium, resulting in high rates of unemployment that last for many years. If this is the case, the obvious next question is what public policies might best contribute to restoring equilibrium on a sustainable rather than just a temporary basis? The insights drawn from the analysis of stocks, the Austrians and Minsky indicate that simple demand side stimulus might not provide a lasting solution to such problems.

\section{Two "Workhorses" and their shortcomings}

In modern academic thinking, New Classical and New Keynesian models of the macro economy became dominant and competing paradigms. However, in recent years, a kind of synthesis has been forged which has led to the popularity of Dynamic Stochastic General Equilibrium models of the economy, even among researchers at leading central banks. All of these models (genetically referred to here as Modern Macroeconomics) have as their primary assumption that the economy has self equilibrating properties in the face of shocks. A second, basic, assumption is that all economic actors have rational expectations which

\footnotetext{
${ }^{4}$ On this specific issue, see White (2009).

${ }^{5}$ This might be thought the principal theme of Leijonhufvud (1968)

${ }^{6}$ For recent historical surveys see Reinhardt and Rogoff (2008) and Schularik and Taylor (2009)
} 
coordinate actions inter temporally. This assumption also ensures that price expectations will be anchored in the policy objectives asserted by central banks.

The purest form of such models is found in the New Classical (or real business cycle) tradition. Here there are no frictions in the economy. All prices adjust instantaneously to clear all markets, ensuring in particular that there can be no involuntary unemployment. New Keynesian models reintroduce the idea (a classical notion but one often attributed to Keynes) that wage and price rigidities (and possibly other "frictions") can cause unemployment to rise in the face of economic shocks, but this is purely a temporary phenomenon. The synthesis of these views, now referred to as the New Neoclassical Synthesis, effectively involved the New Keynesians adopting the modeling methodologies of the New Classical school, and the New Classical School accepting certain "frictions" as realities.

Needless to say, the recent crisis has not been highly supportive of New Classical models based on the assumption that rapidly adjusting prices will quickly reestablish equality between demand and supply, particularly of labour. This assumption seems increasingly inconsistent with observed increases in unemployment ${ }^{7}$ and the sharp slump in output that affected almost all of the global economy. Moreover, even prior to the recent downturn, these models were already under attack on both theoretical and empirical grounds ${ }^{8}$. As for New Keynesian attempts to date to introduce "frictions" into the economy, their influence also seems inadequate to explain the dramatic events still unfolding. Indeed, in addition to sticky wages, there are a whole host of other prices (eg many exchange rates, interest rates both short and long, and the price of energy) that are not in fact free to adjust to market pressures. Rather, they have been significantly influenced by governments pursuing a variety of distributional and other objectives. This interference may, in turn, have inclined the global economy more towards instability than stability. ${ }^{9}$

Nor has the crisis been kind to the assumption of rational expectations which underlies both sets of models. Already under attack on philosophical grounds ${ }^{10}$ (what exactly does it mean to be rational?) the preceding rapid rise and subsequent collapse of a wide range of asset prices hardly seemed consistent with a rational pricing process related to underlying values. Rather, it appears as if expectations in many markets were based largely on the extrapolation of past developments. This led to price levels that eventually proved "unsustainable" as the fundamentals eventually reasserted themselves. Moreover, if it can be contended that momentum rather than rationality drove asset prices, this also raises the

\footnotetext{
${ }^{7}$ A number of years ago, Michael Mussa applied the logic of the New Classical School to the "Great Depression" and renamed it the "Great Vacation"

${ }^{8}$ For a particularly convincing critique see Rudd and Whelan (2005)

${ }^{9}$ Consider, for example, the effort to peg the renmimbi to the dollar, in spite of the US having the world's largest external deficit and China having the world's largest external surplus.

${ }^{10}$ See Foley D K (2004)
} 
possibility that a similar process might be driving inflationary expectations. There is in fact not a very great deal of empirical support for the assertion that low inflationary expectations have been anchored in the stated objectives of central bankers (credibility) rather than the experience of low inflation (good luck) in recent years. ${ }^{11}$

Finally, it needs to be noted that, in models of this sort, there is continuous coordination between individual economic agents (both at a moment in time and across time) through the assumed existence of representative agents and rational expectations. But such assumptions have evident practical shortcomings. First, there is no need for either money or a financial system. To quote Charles Bean (2009), against the backdrop of our continuing problems in the financial sector,

"the fact that financial intermediation plays a negligible role in Mike Woolford's magisterial state of the art opus, Interest and Prices, speaks volumes"

Further, such assumptions imply that exchange obligations are always honored, whether at a moment in time, or across time. In fact, what characterizes the real world in crisis is a systematic failure to honor such obligations. In the private sector, bankruptcies and workouts are common in both the financial and non financial sectors. In extremis, the public sector agrees to meet these obligations in nominal terms but often fails to meet them in real terms as it turns to inflation to erode values ${ }^{12}$.

In short, this crisis (as well as earlier crises) provides evidence that the simplifying assumptions on which much of Modern Macroeconomics is based are not very useful in explaining real world developments. While progress in resolving practical problems can be made by proceeding down this path, it seems likely to take a very long time.

It would be tempting to say that it was the use of these kinds of models by policymakers that led them astray and contributed to our current difficulties. Unfortunately, there is very little evidence that these modern academic theories had much impact on the way that most central bankers have used their policy instruments. Allen Blinder, both a highly respected central banker and academic has written convincingly on this ${ }^{13}$. Rather, most senior policy makers continued to rely on Applied Keynesian Models. However, since these models also failed to provide advance warning of building problems, the specific nature of their shortcomings must also be considered.

One of the great accomplishments of Keynes' General Theory was that it provided a general equilibrium model capable of explaining the simultaneous determination of aggregate

\footnotetext{
${ }^{11}$ For a particular examination of the role of globalization in explaining low inflation see White (2008). For an examination of what seems to determine inflationary expectations, see Rudd and Whelan (2005).

${ }^{12}$ With fiscal deficits rising sharply in most Advanced Market Economies, and with banking systems perhaps requiring further state support, this potential problem is already of great concern to many.

${ }^{13}$ See Blinder(1997) and Blinder (2005)
} 
output, interest rates and (later) prices and inflation. In contrast to classical theory, increases in saving would not (via lower interest rates) ensure that investment rose commensurately to maintain full employment. Rather, aggregate demand (driving income and production) might well fall significantly in the process of ensuring equality between saving and investment. Moreover, if there was one thing that preoccupied Keynes, at least in "The General Theory", it was the reality of, and the need for a policy response to, deep and lasting slumps that demonstrated the fundamental inadequacy of the self equilibrating tendencies in the economy. In this regard, Keynes borrowed from Wicksell the idea that a monetary economy was fundamentally different from a barter economy, and that certain processes (the "paradox of saving" and "accelerator" effects, for example) amplified deviations from full employment equilibrium rather than moderating them.

Shortly after the publication of the General Theory, Keynes's view of the world (which was always hard to interpret) was given a much more concrete form in the IS/LM model suggested by Sir John Hicks. Unfortunately, this mathematically tractable model had to ignore issues that were thought by some to be the essence of Keynes' thought ${ }^{14}$. Nevertheless, this simplified model proved extremely popular and many large empirically estimated macroeconomic models were subsequently built upon this framework. Indeed, a more recent development (made possible by advances in technology) was the imposition on such models of such medium term properties as a return to full employment from whatever starting position. Evidently, this implied a significant deviation from the original Keynesian concern about deep slumps requiring government interventions.

It is important to note that Applied Keynesian Models have never been any good at forecasting turning points in the economy, and they were particularly caught out by the current downturn. This is indeed a fundamental shortcoming, since we hardly need expensive models to assert that the future will be pretty much like the past. Apparently Keynes himself ${ }^{15}$ was profoundly skeptical about the usefulness of such models, which would not be surprising if he felt that their construction ignored some of his most important insights. Expectations, in particular, were thought by Keynes to influence fundamentally all forms of economic behavior. Moreover, given the complexity of the economy, Keynes felt the future was essentially uncertain. Evidently, such a viewpoint has nothing in common with rational expectations. Faced with such uncertainty, economic behavior tends to be guided in large part by heuristic devices and raw emotion ("animal spirits") which can produce highly non-linear outcomes, including deep slumps.

Put another way, Keynes might have agreed that the IS/LM model captured his views in terms of functional forms, but he likely also felt that it could not be estimated. If there was one thing that would characterize the future, it would not be the average of past

\footnotetext{
${ }^{14}$ See in particular Leihonhufvud (1968).

${ }^{15}$ Don Patinkin has documented an exchange of letters between Keynes and Hicks, as well as Keynes' views on the seminal econometric work of Tinbergen.
} 
observations. And to this early criticism of Applied Keynesian Models must be added the later "Lucas critique", as well as the reality of ongoing and massive structural change in the economy which violates the common working assumption of parametric stability in such models ${ }^{16}$.

Finally, it is worth noting that Applied Keynesian models rarely have well developed financial sectors. While the money supply can have an influence on spending, it is generally only to the degree that increases in the money supply reduce interest rates, and these affect spending in turn through a variety of channels ${ }^{17}$. Indeed, in most of these applied models, money and credit have disappeared entirely. They have been replaced by the policy rate, under the influence of the central bank, which is typically guided by something like a Taylor rule. Evidently, without significant detail in the financial sector, the richness of the two way interactions between the health of the real economy and that of the financial system must be almost entirely missing.

To summarize, all of the formal models in common use seem to have significant shortcomings. Modern Macroeconomic models are based on many simplifying assumptions, limiting their usefulness to policy makers. Applied Keynesian Models also have deficiencies, contributing to their incapacity to forecast crises and to accurately gauge the effectiveness of the policy response. One reason could be that some excluded aspects of Keynes' thought are in fact important for understanding how the economy really works. Another possible reason is that all of the above models pay inadequate attention to credit, to stocks and balance sheets (particularly of the corporate and household sectors) and to the possibility of "imbalances" which both lead to crises and subsequently impede recovery.

\section{Credit, Stocks, "Imbalances" and Crises}

All of the models considered above pay limited or no attention to credit aggregates. Moreover, they focus on the determinants of the flow of expenditures (ie aggregate demand) in an economy during a given time period, and allow for demand being either excessive ${ }^{18}$ or deficient.

\footnotetext{
${ }^{16}$ The Lucas critique essentially says that structural relationships depend on policy regimes, and that changes in regime will change structure. The determination of a growing number of central banks to maintain stable prices would be an example of such a regime shift. As for other forms of structural change, think of the effect of globalisation, particularly on the demand and supply of goods and services. As well, within the financial sector, it is well known that the pace of change in recent years has been enormous. Two decades ago, similar changes led to marked instability in estimated demand for money functions and the subsequent abandonment of "monetarism". Since then, the pace of financial change has accelerated even further. It is hard to reconcile these massive changes in the real, monetary and financial sectors with the assumption of parametric stability.

${ }^{17}$ The formulation of the "broad credit" channel, through which monetary policy affects asset values and thus the collateral available to support loans (affecting the risk premium charged to borrowers), was an important advance. See Bernanke and Gertler (1995).

${ }^{18}$ This aspect of Keynes thinking is often ignored. On this, see Keynes (1940)
} 
However, being essentially one period flow models, stocks that build up over time have only a peripheral and gradual influence on people's behavior. Put another way, balance sheet considerations play virtually no role either in explaining crises or shaping the nature of the recovery.

In contrast to this one period framework, Austrian theory focuses on the creation of money and credit by the financial system, and how this leads to cumulative "malinvestments" over many periods ${ }^{19}$. In short, the Austrian approach has more to do with stocks than flows, and focuses more on the processes leading to crises than how to recover from them. For Austrians, "malinvestments" ultimately come down to investments in real capital that will not in the end be profitable, and contracts that will not be honored. Such credit driven processes were expected to implode eventually in the form of an economic crisis of some sort. On the one hand, the crisis might result in a sharp fall in output and outright deflation. On the other hand, if monetary measures were used vigorously enough in response, the end result might be inflation or even hyperinflation. Recall that much of this theorizing was being done against the background of WW1 German debt reparations and the post war hyperinflation in central Europe.

If these Austrian insights provide an important starting point for further analysis, they fall well short of a fully articulated description of how balance sheet effects (including non monetary financial assets and liabilities) can have an impact on economic behavior. Koo (2009) advances the argument one step further ${ }^{20}$ by documenting how high corporate debt levels in Japan led to a decade long collapse in investment as corporations focused on debt repayment. Still another step in that direction has been provided by the Bank for International Settlements (BIS) which, for over a decade, has focused on the more general concept of "imbalances". ${ }^{21}$ By this is meant observations of significant and sustained deviations of economic variables (both financial and economic) from levels that seem justifiable in terms of either historical norms or underlying changes in fundamentals. Such variables would include asset prices, debt levels, spending patterns (saving and investment behavior in particular), trade imbalances and excessive investments in particular sectors that in the end threaten profitability. All of these affect balance sheets in one form or another, and not only the balance sheets of borrowers but also those of lenders. The underlying assumption was that such deviations (as in Austrian theory) were driven by credit expansion

\footnotetext{
${ }^{19}$ In this paper, the emphasis is put on particular aspects of Austrian thinking that seem useful, indeed crucial to our understanding of current events. This should not be taken as a blanket acceptance of all things

"Austrian" since many serious scholars have pointed out both errors and internal contradictions in this way of thinking. See Laidler (1999).

${ }^{20}$ Koo's framework is Austrian in that it focuses on the behaviour of corporate borrowers. However, Koo does not refer to an excess of capital formation leading to an eventual decline in profits. Rather, he notes that credit received from banks was used to buy financial assets that subsequently fell in value. While effectively rendered insolvent, corporations were nevertheless allowed (by the forebearance of both lenders and governments) to work off their debts over time and to avoid insolvency.

${ }^{21}$ For early references, see various Annual Reports of the BIS dating from the middle to late 1990's.
} 
and would eventually collapse. Moreover, their lingering effects would exert significant restraint on the recovery path as well.

To give such thoughts a modern frame of reference, the BIS repeatedly contended that unusually rapid monetary and credit growth over the last decade or so threatened a variety of unpleasant outcomes. On the one hand, an inflationary upsurge was thought a probable outcome as late as the summer of 2008 when commodity prices were rising very rapidly. On the other hand, concerns were also raised about a number of growing "imbalances". First, the rapid rate of monetary and credit expansion was said to have led to asset price increases that seemed to have little to do with fundamentals. Second, it had also led to spending patterns that were well outside historical norms. For example, the household saving rate in many English speaking countries fell to zero or even below, even as the ratio of investment to GDP in China rose to almost 50 percent. Third, as a byproduct of these different domestic imbalances, there was an enormous increase in global trade imbalances.

The danger was always that these "imbalances" would revert respectively to more justifiable and more normal levels. Perhaps most importantly, debt levels would reach heights judged to be unsustainable and spending would be reined back in turn. Overextended bankers would then no longer wish to lend and debtors would no longer wish to borrow. Starting in the fall of 2007, and accelerating through the middle of 2008 to mid 2009, we saw a financial and economic reversal having this predicted nature. While triggered by a crisis in the financial sector, the cause was firmly rooted in the underling "imbalances".

Both asset prices and consumer spending in the United States, the United Kingdom and a number of other countries began to revert to more normal levels. As rates of household saving rose in an effort to pay down debt, spending and the economy slowed. Investment slowed dramatically as did investment in inventories. The fact that the stock of outstanding durable goods and houses had in many cases expanded enormously put further downward pressure on the price of such goods, leading to further balance sheet deterioration. Household bankruptcies rose sharply in the United States, in particular, and more are expected. Moreover, these reversions also inflicted enormous damage on the financial institutions that had extended too much credit in the first place. These developments were at the heart of the global slowdown, and they remain the source of concerns about "fragility" going forward, in spite of the more recent economic recovery. From this perspective, even the unprecedented credit-fuelled growth of fixed investment in China would have to be seen more as a danger signal than a sign of renewed sustainable growth.

It is particularly important to note that the initial Austrian insight ("malinvestment") goes beyond the effects of credit on various components of demand. It assumes that supply responds, raising the possibility of a fourth kind of "imbalance". Mistaken spending decisions result in stocks of unprofitable (for corporations) or undesired (for households) stocks of investment/durable goods that will take a significant time to depreciate. To again put this in 
a current perspective, many industries which have expanded sharply in response to high demand are now "too big" and must shrink. Such industries at the global level would include financial services, car production, wholesale distribution (particularly global supply networks), construction, and (for a time at least) many other intermediate and primary inputs such as steel, aluminum and cement. Moreover, with many production facilities in Asia now geared up to sell to foreigners, who no longer have the means to pay (nor the willingness to borrow further), a major geographical reallocation of production facilities also seems inevitable.

During the significant time that all this restructuring will take, the structural rate of unemployment will be higher and the level of potential will be lower. Moreover, these effects on potential will come on top of the more traditional effects of downturns leading to lower investment (sometimes suppressed by tighter credit conditions) and hysteresis in the labor market ${ }^{22}$. This implies that all policies to expand aggregate demand could stimulate inflationary pressures sooner than some might expect. Given that some of these policies (e.g. Quantititative and Credit Easing) are themselves unprecedented, and their effects on demand commensurately uncertain ${ }^{23}$, the added uncertainty generated by shifts in aggregate supply raises the likelihood of policy mistakes that might culminate in either inflation or deflation.

If the treatment of "imbalances" in popular macroeconomic analysis needs to be improved, so too does the treatment of the financial sector. The popular shorthand for our current difficulties is the "global financial crisis", which suggests that financial issues are being increasingly recognized as important ${ }^{24}$. Admittedly, it has always been understood that bankers create money and credit. Indeed, this was seen (by the Austrians at least) as being at the heart of the crises which emerge from time to time in capitalist societies. However, even in that literature, problems within the financial sector and negative feedback effects

\footnotetext{
${ }^{22}$ See Cerra and Saxena (2008)

${ }^{23}$ The level of demand going forward will, in any event, be extremely uncertain. In particular, it will depend on household spending decisions subject to unprecedented levels of debt in many countries, sharp variations in asset prices, and a degree of tightening of credit conditions that will depend on the health of the financial system. Putting all these risks together might well imply that we have entered the realm of Knightian uncertainty when it comes to policy formulation.

${ }^{24}$ The popular shorthand that says we are currently facing a "financial crisis" could also imply that some deficiency in the operation of the financial sector provides a full explanation of what has gone wrong. This latter extension would, in fact, constitute a serious misperception. As will be discussed further below, the crisis has deep roots in the interactions between the real and financial sectors. It has not been caused by the financial sector alone. This misperception is due, perhaps, to the fact that the catalyst for the crisis (rather than its cause) was the set of difficulties which arose in the market for subprime mortgages in the United States. This perception might also have been supported by the associated popular concern that weakness in the financial system could feed back on the real economy through tighter credit conditions. Perhaps an even more important reason for the focus on financial sector problems is the fact that the public always needs someone to blame in times of crisis. This time it has proved convenient to blame the financial sector in general, and bankers in particular.
} 
from a wounded financial sector to the real economy are hardly mentioned. Irving Fisher (1936) provided another early attempt to analyze such interactive processes. Against the background of thousands of bank failures in the United States in the early 1930's, he spoke of successive stages of lending with ever easier credit conditions ${ }^{25}$. In the end, this laxity threatened the banks themselves, their willingness to extend further credit, and the capacity of the economy to recover.

For a fuller evaluation of the dynamics of such financial processes, however, we need to turn to Hyman Minsky whose "Financial Instability Hypothesis takes banking seriously as a profit making activity" ${ }^{26}$. Like Fisher, Minsky spoke of stages of credit growth, with the horizon of the credit getting shorter at each stage. The process would culminate in what was essentially Ponzi finance, when loans at the last stage of the boom would be used to pay the interest on previous loans. Moreover, Minsky felt that an evolution towards lower and lower lending standards was inevitable.

"over periods of prolonged prosperity, the economy transits from financial relations that make for a stable system to financial relations that make for an unstable system"

Fundamentally, for Minsky, stability breeds instability. The process of credit creation ends at a moment, impossible to predict in advance but catalyzed by some external event, when creditors suddenly admit to their past excesses. They naturally focus first on their own exposures, but then almost instantaneously on what they assume to be the even more imprudent behavior of others. At this "Minsky moment" the downward phase of the credit cycle begins, with important implications for the real economy. Note, moreover, that while it looks like a liquidity crisis, the underlying reason for the drying up of credit is (for Minsky) deep concerns about the insolvency of counterparties, including other banks.

Consider the market's reaction to the decision by BNP in August 2007 to freeze withdrawals from three of their off balance sheet vehicles. Consider also the market's subsequent reaction to the unexpected failure of Lehman Brothers. In effect, the interbank term market dried up completely, and almost instantaneously, as did many other markets including those for asset backed commercial paper and virtually all securitized products. There would then seem to be a lot in the work of Minsky that could be relevant to our current problems. One important implication of this interpretation of events is that the crisis should ideally have been treated as a solvency (rather than just a liquidity) problem to begin with. Evidently, absent adequate legal mechanisms, this was not possible in practice. This issue is returned to below.

\footnotetext{
${ }^{25}$ The last of these he speaks of as aiding "speculation and outright fraud". That this is a common observation in the late stages of major credit booms is attested to by Kindelberger and Aliber (2005) who devote a whole chapter to such events in past cycles. In this historical context at least, Bernie Madoff did not act alone.

${ }^{26}$ Minsky (1992).
} 


\section{Some Suggestions for Macroeconomic Theory}

What do the above considerations seem to imply for the future of macroeconomic theory? The simplifying assumptions of the New Classical and New Keynesian models do not make them obvious candidates for near term guidance as to how best to conduct macroeconomic policies. As Mankiw (2006) describes it, theirs is the work of "scientists" and not "engineers". The practical payoff could take decades, if ever.

As a practical matter, we might begin by trying to improve the analytical models currently used by policymakers. The first challenge might then be to try to reintroduce some elements of the "Economics of Keynes" that have thus far been excluded from such models. ${ }^{27}$ In particular, what are the implications for the reestablishment of full employment (after a shock) of heterogeneous economic agents having different appetites for risk, expectations and access to information, and also being subject to a variety of constraints ${ }^{28}$. At a minimum, an improved Keynesian approach would recognize the essential fuzziness and uncertainties implicit in the "animal spirits" that drive the main functional forms of the models based on "Keynesian Economics".

This latter point implies in turn being considerably more skeptical about the forecasts thrown up by the currently used empirical models of this type. Indeed, experience of very large forecast errors at turning points, not least by the IMF, OECD and other official bodies, has contributed to a trend evident in most forecasting shops for many years. Conscious of the potential shortcomings of individual models, many institutions have already begun to maintain a variety of such models. Judgments about policy requirements are then based on an overview of them all, plus whatever intuition experienced policy makers are prone to add in. This approach is often spoken of as a desirable blend of "art and science". However, if all the models being considered suffer from essentially the same analytical flaws, the "science" component would hardly seem to deserve such a designation.

But there are other challenges to the conventional way of doing things as well. How can we blend into this improved Keynesian framework some of the insights of Austrian theory, in particular concerns about "imbalances" that both lead to crisis and impede recovery? Under normal circumstances, using a Keynesian framework straightforwardly to project output gaps and inflationary tendencies might seem quite satisfactory. For example, earlier in this decade, such a framework seemed to provide an adequate explanation for the simultaneous

\footnotetext{
${ }^{27}$ Leijonhufvud (1968) in the title of his book distinguishes between "Keynesian economics and the Economics of Keynes". The former he considers to be the popular version of Keynesianism discussed above, while the latter is what Leijonhufvud contends Keynes actually believed.

${ }^{28}$ Among these would be included sticky nominal wages, the zero lower bound for nominal interest rates, and financial contracts written in nominal terms. In the event of falling prices and squeezed profit margins, all of these might lead to an aggravation of the severity of downturns arising from whatever cause.
} 
observation of rapid growth, falling inflation and very low real interest rates ${ }^{29}$ in the global economy. However, beneath this calm surface, "imbalances" were building up that eventually culminated in the current crisis $^{30}$. The future macroeconomic research agenda must find ways to identify and react to these cumulative pressures. Fortunately, there has already been a significant amount of work done in the area of identification, and some promising areas for further progress have been suggested. ${ }^{31}$

One tendency that must be resisted is to see this work on imbalances as being related solely to "financial stability". In part, this tendency is related to the misconception noted above that our current problems have been initiated by and are limited to the financial sector. Rather, an important dimension of the Austrian interpretation of the current set of problems is that excessive credit and monetary creation can lead to imbalances outside the financial system with significant macroeconomic implications. Today, for example, households in the United States and a number of other countries seem likely to spend less, to save more, and to try to pay down debts. This seems likely to happen regardless of the capacity or incapacity of the financial system to give previous borrowers still more credit ${ }^{32}$. How the state of household and corporate balance sheets affects the desire to spend (as opposed to the capacity to spend) is a crucial issue for future research.

Viewing the issue as a broader macroeconomic problem, rather than the narrower problem of "financial stability", also has important institutional implications. It implies that the ultimate responsibility for monitoring the buildup of these kinds of imbalances, and for directing the policy response, falls more naturally into the realm of central banks than into the realm of financial supervisors. This currently creates a political problem, since it also appears that regulatory instruments, particularly ones that can be based on rules rather than discretion $^{33}$, seem currently to be the preferred policy response to the buildup of these kinds

\footnotetext{
${ }^{29}$ White (2008) used a global IS/LM model with a vertical real supply schedule to explain the unusual joint phenomena of very rapid growth, very low inflation and very low real interest rates earlier this decade. All three are explained by a positive supply side shift (due to globalization and other factors), a downward shift in the IS function (due to a collapse in investment and higher saving rates in Asia) and a resulting downward shift in the LM schedule (as central banks responded to the growing gap between aggregate demand and supply).

${ }^{30}$ Leijonhufvud has written extensively on what he calls the "corridor of stability". The basic idea is that economies are stable and self equilibrating only within certain limits. Pushed beyond those limits, destabilizing tendencies predominate. See Leihonufvud (2009).

${ }^{31}$ For an overview of this work see Borio and Drehmann (2009)

${ }^{32} \mathrm{Koo}$ (2008) contends that the length of the period of stagnation in Japan (beginning in the early 1990's) was largely determined by the efforts of corporations to pay off debts. He further contends that the weakened state of the Japanese banking system played only a very limited role in explaining this phenomenon.

${ }^{33}$ Consider wide spread suggestions that banks use dynamic provisioning of the kind imposed in Spain, or that capital requirements under Basel 3 somehow be made countercyclical. See Basel Committee on Banking Supervision (2009). The preference for rule based regimes seems to reflect the belief that discretionary "leaning against the wind" of credit bubbles will prove very difficult from both a technical and political perspective. See Brunnermeier et al (2009).
} 
of problems ${ }^{34}$. Further research into these questions would be very welcome. In particular, the scope for monetary policy to "lean against the wind" of rapid credit growth should receive significant attention. ${ }^{35}$

To say that the problem is a broad macroeconomic problem is not to deny that it has a crucial financial component. Imbalances and excessive leverage in household and corporate balance sheets will generally be matched by excessive leverage on the part of financial firms. Indeed, it is the need to unwind both sets of leverage simultaneously that tends to make credit driven economic downturns so severe. The effects of the non-financial deleveraging on the economy will be amplified by Keynes' "paradox of saving", while financial deleveraging will be impeded by what Fisher (1933) described as the "paradox of deleveraging". In short, if we are to follow up on the insights of Minsky, research into the functioning of the financial system remains a high priority.

The current crisis has also led many to disavow most versions of efficient market theory, but what is to replace it? Again, and fortunately, there already exists a body of finance literature on information deficiencies, network problems, flawed incentives and the like. The insights of behavioral finance are also being treated increasingly seriously, as are the contributions of market practitioners with particular insights into the interactions among participants that can generate unwarranted market outcomes ${ }^{36}$. Recent advances in network theory and the theory of complex systems ${ }^{37}$ could also prove useful, particularly to the extent they might throw light on the robustness of the payments infrastructure (the "plumbing") supporting the whole financial system.

It is worth noting separately one example of market inefficiency that is likely to have particular implications for macroeconomic policies and even institutional reform. The Theory of Uncovered Interest Parity does not hold except over quite long time periods. ${ }^{38}$ This implies that interest rate differentials across countries can induce capital flows ("carry trades") for equally long periods, as investors tend to ignore the possibility of an eventual depreciation of the currency of the country receiving the capital inflows. For the domestic monetary authority, this poses a potentially severe problem. Higher policy rates could potentially induce enough inflows, with associated implications for domestic credit conditions and the prices of longer term assets, to lead to an overall easing of financial conditions rather than the desired tightening. While it is tempting to think that this problem

\footnotetext{
${ }^{34}$ This is the thrust of many official studies into the future of financial regulation. See the Paulsen Treasury report in the US, the report of the de Larosière group in Europe and the Turner report in the United Kingdom. ${ }^{35}$ On this see White (2009)

${ }^{36}$ For an example of the former, consider Akerlof and Schiller (2009) and, for the latter, Soros (2009)

${ }^{37}$ For a recent overview of this literature see Ramsden and Kervalishvili (2008)

${ }^{38}$ This is but one of many problems caused by what has been called "short-termism"in financial markets; namely, behavior which focuses on short term gain while ignoring longer term risks. Examples of such behavior would include the writing of longer term options to reap the benefit of a steady inflow of (inadequate) premia, and making loans on the basis of collateral (subject to changes in value) rather than future cash flow.
} 
only applies to very small open economies, this may not in fact be true. Consider that, in the United States, monetary tightening at the end of the 1990's and again after 2003 did not initially have the desired effects. As the dollar strengthened, equity prices rose and long bond rates fell. In part, this was due to the recycling of trade receipts, and capital inflows into emerging market countries, back into the United States. Recipient countries both intervened in foreign exchange markets (accumulating foreign exchange reserves) and eased monetary policy to prevent their exchange rates from rising. This contributed materially to an increase in global liquidity which further fuelled existing "imbalances".

For smaller countries at least, this "carry trade" phenomenon raises the shorter term issue of the need for capital controls. Longer term, it is also relevant to a broader institutional question. If floating, in the context of free capital flows, amplifies the domestic credit cycle rather than moderating it, one of the main arguments for having a separate currency is called into question. For larger countries, whose currencies are used to fund such capital flows, a still broader question arises. Should large countries take into account the externalities (effects on other countries) of their domestic policies, particularly the very low policy rates increasingly being relied upon to revive economies in the aftermath of credit bubbles? Such reflections invite more research into the operations of the international monetary system, and how shortcomings in this area may have contributed to the current crisis.

As with the broader macro problems, new ways of thinking about financial problems can also have important institutional implications. No question is currently more important than the role of government safety nets. In various ways, they have been expanding for decades, and we have just observed another massive step in that direction ${ }^{39}$. The extent to which the growing moral hazard (flawed incentives, noted above) associated with this trend has contributed to the growing severity of successive financial cycles is a topic that cries out for the attention of researchers. ${ }^{40}$ Current concerns that banks have become too $\mathrm{big} / \mathrm{complex} /$ interrelated/to fail/ save/ are certainly warranted, but they are only one aspect of this much bigger issue.

\section{Some Implications for Macroeconomic Policy}

What do the above considerations imply for macroeconomic policy in normal circumstances? The most important implication would be that policy should be focused much more on avoiding future crises arising from the accumulation over time of "imbalances" in both the real economy and the financial sector. This implies a multi period as opposed to a single period policy horizon. To this end, we need to institute a new

\footnotetext{
${ }^{39}$ See Allesandri and Haldane (2009)

${ }^{40}$ On the possibility that successive bouts of monetary easing lead to a progressive reduction in the capacity of monetary policy to stimulate demand, see White (2006) and White (2009). Soros (2009) makes a very similar point in referring to the bursting of a "super bubble".
} 
framework for macrofinancial stability that would involve monetary, fiscal and regulatory policies leaning more systematically against the upswing of the credit cycle. Evidently, this would lead to a more symmetric application of such policies over the cycle. Moreover, it would also demand more overt cooperation between the various arms of domestic governments than is currently the case, and more international cooperation among governments as well. These issues have been dealt with at length elsewhere, and need not be pursued further here. ${ }^{41}$

Closely related, policies directed to lowering the probability (and costs) of major crises would likely have to be more tolerant of minor downturns than hitherto ${ }^{42}$. In a multi period world, such downturns clearly have welcome therapeutic effects. If big crises have their roots in wide spread debt problems, then recessions help prevent such buildups. Not only do they directly reduce debt levels through bankruptcies and debt workouts, but the threat of such an outcome leads to more prudent behavior with respect to debt accumulation (and leverage) in the cyclical upswing. Evidently, all bankruptcies have their downsides, but in relatively small numbers they are manageable. In contrast, widespread bankruptcies which threaten the stability of the financial system, or produce very large costs (via bailouts) for taxpayers, are inherently much more difficult to manage. Indeed, in the limit, where even the solvency of the government is called into question, the temptation to use the printing presses to paper over the problem could prove irresistible. And, since only unexpected inflation has this effect, the required increase in inflation could become very large ${ }^{43}$.

What do the above considerations imply for macroeconomic policy in current circumstances, where many countries are still deeply affected by the recent crisis? What policies would help to foster a global recovery on a sustainable rather than only a temporary basis? The fundamental Keynesian insight, that raising aggregate demand is a high priority, will not be challenged in this paper ${ }^{44}$. Yet, those who worry about side effects stretching beyond the current period would note two important implications. First, there should be a bias towards earlier "exit" policies to reduce the medium term costs of these policies. Second, forms of spending which actually increase imbalances are not sustainable and should not be relied upon.

\footnotetext{
${ }^{41}$ See in particular, White (2005) White (2009) and Hannoun (2010)

${ }^{42}$ Some might contend that this would be very difficult to do politically. While likely the case, note that the political authorities in many countries have already gone a long way down this road by giving "independent" central banks a mandate for keeping inflation low. Evidently, if the central bank's tightening to avoid inflation is not perfectly implemented (and it almost never is) recessions are implicitly accepted as being the cost paid to achieve price stability.

${ }^{43}$ Reference is made here only to the economic costs of deep slumps. Recall that Keynes, Hayek, Schumpeter and others in the1930's worried as well about the social and political implications, not least threats to democracy and capitalism itself.

${ }^{44}$ Even Hayek was prepared to accept the usefulness of policies to stimulate aggregate demand in the case of what he called a "secondary depression". By this he seemed to mean a cumulative downward process independent from the "maladjustments" that catalyzed it.
} 
Concerning a bias to an earlier introduction of "exit" policies, the concerns in the case of fiscal policy are felt instinctively ${ }^{45}$. After many decades of expansionary fiscal policies to fight recessions, and inadequate tightening in upswings, there is concern in many Advanced Market Economies that high and still rising debt to GNP ratios could cause financial markets to demand compensation for increasing risks of non-payment. This could exert upward pressure on longer term interest rates ${ }^{46}$ and downward pressure on the sovereign's currency, leading in some cases to a stagflationary outcome.

In response to concerns about high and rising debt levels, Ireland and Hungary, among others, were among the first to use discretionary fiscal tightening to offset major increases in deficits due to the operation of automatic stabilizers during the downturn. Many other larger countries, like the United States and the United Kingdom, have been urged to at least prepare and present credible plans for stabilizing the public finances once the economy recovers. Indeed, the recent European crisis (which began in Greece) led to a number of European countries slashing deficits further in spite of already large negative output gaps. Supporting these actions is a significant body of research indicating that fiscal restraint, especially through expenditure reduction, leads to slower growth initially but then faster growth subsequently. ${ }^{47}$

There is less instinctive understanding of the undesirable medium term effects of very expansionary monetary policies, but it is by no means a "free lunch". The first worry is that such policies will prove effective only by stimulating a "bubble"in some new market and still further increases in leverage and indebtedness. Indeed, as noted above, there are grounds for belief that we have been on such a path for many years ${ }^{48}$. A second worry is that very easy monetary policy reduces growth potential in various ways. In particular, saving rates are reduced (affecting the capital stock over time) and "zombie" companies and banks are allowed to survive and (through competition effects) drag down the living with them ${ }^{49}$. The subsequent effects on private sector investment, and reductions in aggregate demand, are referred to below. A third worry is that the "search for yield" will strongly encourage imprudent lending and the development of new instruments to hide risk ${ }^{50}$. Fourth, at very low interest rates, the interbank market will collapse leaving the central bank as the market

\footnotetext{
${ }^{45}$ For the IMF, fiscal restraint in the face of downward pressure on the currency has been a traditional recommendation even if implies an economic slowdown. The logic has been that a full blown crisis would cause even more economic damage.

${ }^{46}$ Of course, this leads to a vicious circle. Higher interest rates increase debt service requirements which makes the initial fears of non payment worse. See Checcetti et al (2010)

${ }^{47}$ See Guichard et al (2007) and Alesina and Ardagna (2009).

${ }^{48}$ For a fuller discussion see White (2005. Since such a process must also prove unsustainable, the extensive and repeated use of such policies are not to be recommended. Unfortunately, however, the further down this path a monetary authority finds itself, the more apparent become the costs of trying to deviate from that path. 49. On "zombies" in Japan, see Aherne and Shinada (2005) and Peek and Rosengreen (2003). They document how Japanese banks "evergreened" the loans of troubled firms, and how productivity growth suffered in industries containing such troubled firms.

${ }^{50}$ On the "risk taking channel" see Borio and Zhu (2008). On new instruments see Rajan (2005).
} 
maker of last resort. And finally, as noted above, there is the worry that extraordinarily easy monetary policies (various forms of quantitative and credit easing) might inadvertently culminate in rising inflation.

Closely related to these concerns about the negative medium term effects of using macroeconomic policies to support the financial sector and the real economy would be concerns about the use of other policies for similar ends. In most countries, direct government intervention to support the private financial sector has increased moral hazard, although it has not yet succeeded in clearly resolving existing problems. Moreover, mergers and acquisitions in many countries have resulted in larger banks, further consolidation and increased complexity. All of this has made the "too big to fail" problem even worse ${ }^{51}$, again implying still greater problems ahead.

As for support for the real economy, many countries (particularly in Europe but also Japan) have introduced programs to encourage companies and workers to stay in their jobs on a part time basis. While this might help maintain income flows and spending, it could also (from an Austrian "malinvestment"perspective) have less desirable effects over a longer time frame. This would be particularly so if its effect was to impede necessary adjustments to production capacities. As Schumpeter once put it ${ }^{52}$

"Most of what would be effective in remedying a depression would be equally effective in preventing this adjustment. This is especially true of inflation which would, if pushed far enough.......lead to a collapse worse than the one it was called in to remedy. "

To be still more concrete, "cars for clunkers" programs in countries with very low household saving rates are not optimal. Nor are attempts to hold down exchange rates by countries with huge external trade surpluses. Nor are wage subsidies to support part time work, if jobs in the industries being supported (cars, construction, banking services etc.) will never fully recover $^{53}$. However desirable in terms of near term effects, adopting a multi period perspective implies that countries should exit from such policies sooner rather than later.

A second policy recommendation, suggested by a multiperiod perspective, would be to avoid encouraging forms of spending that would increase existing imbalances. It is helpful here to look in turn at the various components of aggregate global demand in the National Income Accounts. To start with, there would seem to be little room to increase consumer spending and residential investment in many countries, not least the United States. Debt levels and

\footnotetext{
${ }^{51}$ By "too big to fail" is normally meant "too big/complex/interconnected to be allowed by governments to fail in a disorderly way".

${ }^{52}$ Schumpeter (1934) p16

${ }^{53}$ It is notable that most of the countries with short time work programs to support jobs in the tradeable goods industries are countries with large external trade surpluses. If such surpluses are "unsustainable",then presumably so too are many of the current jobs in those industries.
} 
the stocks of such goods are already uncomfortably high. As for fixed investment, there would seem little room for this in China where investment is already an unprecedented 50 percent of GDP, ${ }^{54}$ and where an added concern is that such investment will be directed towards the production of exports that could worsen global imbalances. As for government contributions to aggregate demand, as just noted above, many countries now have deficits and debt levels that are already contributing to higher sovereign risk spreads or threaten to do so. These governments thus have little room for maneuver. Finally, for individual countries like the United States, demand could emanate from the external sector. However, this is of no net gain to the global economy as a whole. Other countries, most notably China, Germany and Japan, would by definition have to run smaller external surpluses. In short, Keynesian solutions to the current crisis must be "constrained Keynesian" solutions if they are to be sustainable.

Taken all together, the above observations might be thought to constitute a council of despair. In fact, this need not be the case. Although adoption of a multi period perspective suggests that there are no quick fixes for our current difficulties, it also points towards other policies that could lead to a sustainable recovery over a rather longer time horizon.

Perhaps the first thing to recognize is that not all global spending categories are debt constrained. In the emerging market economies, consumption levels are low, saving rates are high and consumer debt is not a domestic constraint. Since many of these countries (especially China) are running large current account surpluses, there are no external constraints either. A number of the advanced market economies (Germany, Japan and Switzerland for example) find themselves in a very similar external situation. A global (G20) initiative to encourage a sustainable recovery should emphasize consumption spending in such countries. Structural reforms (of which more below) to encourage the production of domestic services in such countries would also be very welcome ${ }^{55}$. As a corollary, if these countries were initially pressing up against production limits, it would also be imperative to allow their exchange rates to strengthen to avoid domestic inflation.

There would also seem room for increases in private sector investments in many countries where investment levels have been low for many years. While private sector investment should always await the identification of profitable opportunities, such developments as demographic change and climate change would seem to offer such opportunities almost everywhere. As well, many countries with large trade deficits need more investment in the

\footnotetext{
${ }^{54}$ Albeit, this is more of a "speed limit issue" having to do with rapid capital expansion leading to bad investment decisions. There can be little doubt that China remains an emerging market economy with a capital stock that is still relatively small compared to its population.

${ }^{55}$ This has been a long standing recommendation, in chapters on structural issues, in the country reviews carried out by the Economic and Development Review Committee at the OECD. See as well Jones and Yoon (2008)
} 
production of tradable goods and services to allow those deficits to narrow to more sustainable levels.

Governments could play a big role here, for better or for worse. Perhaps most importantly, private sector investment will not be stimulated by a political environment which is anti business. A number of authors have suggested that the depth and magnitude of the Great Depression in the United States, owed a great deal to such negative attitudes ${ }^{56}$. Further, a climate of uncertainty about prospective government policies would also inhibit private investment.

Finally, governments must allow a number of important prices that they (along with central banks) influence strongly to reflect market forces more faithfully. As noted above, unnaturally low interest rates help to keep "zombie" companies and banks alive. The competition provided by such companies could be a direct major impediment to new private sector investment. As well, tolerating an unhealthy banking system raises the likelihood that it will be incapable of providing the financing needed for new investments. Small and medium size enterprises that traditionally create the most jobs might be particularly hurt by such a shortfall. In this respect, there is much to learn from the Japanese experience of the 1990's and more recently.

As well, fewer energy subsidies ${ }^{57}$ (particularly in emerging market economies) and energy prices that better reflected externalities (carbon taxes and "cap and trade" processes) would encourage global investment consistent with resisting climate change. Reducing the various subsidies in China which encourage the manufacturing sector would encourage investment prospects elsewhere. So too would allowing exchange rates to move to reflect the buildup of global trade imbalances. Entrepreneurs in countries with trade deficits have to be confident they will have market access to countries with trade surpluses ${ }^{58}$. Evidently, concerns about protectionism would be a strong influence in the opposite direction.

Public sector investment would also seem likely to have a high rate of return in many countries. In many emerging markets, a great deal of necessary infrastructure for growth is missing. In many advanced market economies, depreciation has taken a huge toll on old public sector investments, implying the need for new programs. The suggestion that the recession might be over before these investments could be planned and executed does, of course, carry less weight for those who feel the "headwinds" of the imbalances will be blowing strongly for a long time. Of course, in the case of countries with large existing public debts, financial markets would still have to be convinced that the prospective government

\footnotetext{
${ }^{56}$ See Powell (2003) and Smiley (2002)

${ }^{57}$ Recent estimates by the OECD indicate that almost $\$ 500$ billion is spent on such subsidies each year worldwide.

${ }^{58}$ Higher exchange rates for surplus countries also encourage more consumption in such countries, even if lower exchange rates have the opposite effects in deficit countries.
} 
assets would yield more in terms of growth and tax revenues than the cost of financing them. Failing this, it might also be possible to raise tax revenues in ways that reduced private spending by less than the prospective increases in public sector spending ${ }^{59}$.

In addition to expanding spending where there are no debt constraints, attempts could be made to reduce the existing constraints on spending, thus improving spending prospects going forward. In particular, a rapid writing off of the debts themselves, and the scrapping or reallocation of the assets purchased with borrowed money, would have many benefits. Evidently, orderly workouts designed to maintain value would be preferable to bankruptcies, but in many cases the latter might be inevitable. Of particular importance would be reductions of consumer debt in the United States and other countries that had similarly overspent, and reductions of corporate debt in countries with export led growth strategies that were no longer sustainable. Evidently, such efforts would also have important implications for private sector investment, in that they would free up (and make less expensive) factors of production.

In many countries, bankruptcy laws and workout procedures could be much improved, and greater effort should be put into developing the kind of practical expertise required to fully exploit such laws and procedures. Evidently, there are other considerations that might constrain efforts in this area ${ }^{60}$, but its importance should not be underestimated. There are many who contend that the lost decade in Japan was primarily due to a failure to grasp this particular nettle ${ }^{61}$.

Evidently, debt restructuring will have big implications for lenders as well as borrowers. In fact, fears about such implications could well constitute the single biggest constraint on a restructuring process. While much has been written on this, there seems general agreement that the approach taken by the Nordic countries to their problems of over indebtedness in the early 1990's had much to recommend it. In particular, the state guaranteed all the liabilities of the banks, and put the restructuring decisions in the hands of technicians completely independent of the political process. The fact that the respective Nordic governments had the full support of all the other political parties provided a guarantee of "finality" that helped the process materially. Unlike the Japanese, the Nordic countries

\footnotetext{
${ }^{59}$ By way of example, the tax structure of the United States seems relatively inefficient. Higher property taxes, introduction of a VAT and other "sin" taxes, and the reduction of interest deductibility for corporate and households could raise major revenues and also have other benefits. These would include more work and more saving. A reduction in the corporate tax rate and the double taxation of profits, offset by lower interest rate deductions, would also encourage more investment and greater reliance on equity rather than corporate debt. ${ }^{60}$ In the US, there are millions of households in difficulty and even the US does not have the infrastructure to cope with this. Further, much mortgage debt is encumbered by "silent second" mortgages and by being wrapped up in structured products where restructuring of the underlying asset is not allowed. See Ellis (2008). In China, much investment has been carried out by State Owned Enterprises and sub national levels of government. The politics of "writeoffs" in such circumstances would be an enormous impediment to action. ${ }^{61}$ See the references above to "zombie" companies. As well, see Toyama and Sato (2007) and Nakamae (2010)
} 
resumed rapid growth after only a few years of deep recession and that stellar performance was maintained until the global crisis intervened in the middle of 2008.

This Nordic experience shows that it is possible to resolve debt problems, even those big enough to threaten the whole banking system. Whether other governments and other political systems would be capable of such resolute action remains to be seen. The fact that the inter linkages between financial agents have become much more complex and nontransparent in recent years is a further significant impediment to confronting this issue head $\mathrm{on}^{62}$. So too is aggressive lobbying by financial sector interests in favor of the status quo. At the least, their argument that more aggressive official polices will slow economic recovery needs to be confronted with the facts of the Nordic experience.

\section{A Methodological Postscript}

When it comes to macroeconomic theory, the current crisis has highlighted what appear to be some serious shortcomings of prevailing modes of thought. At the same time, it has also raised the prospect of other strands of thought with important implications for policy. A multi period perspective, recognizing the procyclical interactions over time between the real sector and the financial sector, can improve polices directed to both crisis prevention and crisis management. Perhaps most important, it provides some guidance as to how policy can be used in the current crisis to prepare the way for a more sustainable global economic rebound. Whether such suggestions will prompt research work leading to an eventual "paradigm shift" remains to be seen. But, however we label it, a change in how most economists think about macroeconomic processes would seem highly desirable.

A corollary thought is that the complexity of the interacting influences on the economy will likely never be amenable to rigorous mathematical proof. Macroeconomics is not a science, regardless of how many economists who would like to believe that it is. We must then be ready to accept other kinds of "proof", or at least guides to policy decisions, perhaps along the lines suggested a number of years ago by McClosky (1985). Insights from economic history and the history of economic thought could have a particularly important contribution to make to our understanding of how things work. This is particularly so given the economic and financial liberalization of recent decades. Deregulation and globalization has made our current world resemble much more the one seen a century or more ago, albeit much faster and more complex, than the one that prevailed in the decades following War II.

\footnotetext{
62 The so called" Volcker" plan to force banks to stop proprietary trading has been criticized on the grounds that proprietary trading was not at the heart of current problems in the financial sector. This criticism misses the point. Such trading is at the heart of the inter linkages and complexities which made the official sector so fearful of either letting banks fail or nationalizing them outright.
} 
And, as a further corollary, policymakers might be well advised to replace their current "maximizing" strategies with their "minimax" equivalents. Given our current degree of ignorance about how the macro economy actually works, a philosophy of "do no harm" would seem to have much to recommend it. In that sense, perhaps, economists would do much better to emulate doctors rather than dentists. ${ }^{63}$

\footnotetext{
${ }^{63}$ Keynes once said "If economists could manage to get themselves thought of as humble, competent people on a level with dentists, that would be splendid." In contrast, doctors (like the ancient Greeks taking the Hippocratic oath) pledge to "do no harm". This would seem even more welcome, being a significantly less ambitious objective.
} 


\section{Bibliography}

Ahearne, A G and Shinada N (2005) "Zombie firms and economic stagnation in Japan" IEEP 2: 363381, November

Akerlof, G A and Shiller R J (2009), "Animal Spirits, How Human Psychology Drives the Economy and Why it Matters for Global Capitalism" Princeton University Press, Princeton

Aleina, A F, and Ardagna, S (2009) "Large changes in fiscal policy: Taxes versus spending" NBER Working Paper Series No 15438, Cambridge Mass

Basel Committee on Banking Supervision (2009) "Strengthening the Resilience of the Banking Sector" Basel, December

Bean,C (2009) "The Great Moderation, the Great Panic, and the Great Contraction" Schumpeter Lecture, Annual Congress of the European Economics Association, Barcelona, 25 August

Bernanke, B S and Gertler M "Inside the Black Box: The Credit Channel of Monetary Policy Transmission" Journal of Economic Perspectives, Vol.9 Number 4, pp27-48

Blinder, A (1995) "Central Banking in Theory and Practice" Marshall Lectures, University of Cambridge, Cambridge, May

Blinder, A S (1997) "What central bankers could learn from academics- and vice versa" Journal of Economic Perspectives, Spring, 3-19

Borio, C and Drehmann, H (2009) "Towards an operational framework for financial stability: fuzzy measurement and its consequences" BIS Working Paper 284, June

Borio, C and Zhu, H (2008) "Capital regulation, risk taking and monetary policy" BIS Working Paper 268, December

Brunnermeier, M, Crockett A, Goodhart C A E, Persaud A D, and Shin H (2009) "The fundamental principles of financial regulation" International Centre for Monetary and Banking Studies, May, Geneva

Cerra, V and Saxena, V (2008) "growth dynamics: the myth of economic recovery" American Economic Review, American Economic Association Vol 98(1) pp 439-457

Cecchetti,C M Mohanty and Zampolli $F$ (2010) "The future of public debt: prospects and implications" BIS Working Paper 300, March

Ellis, L (2008) "The housing meltdown: why did it happen in the United States?" BIS Working Paper 259, September

Fisher, I (1933) The Debt-Deflation Theory of Great Depressions" Econometrica

Foley, D (2004) "Rationality and Ideology in Economics" Journal of Social Research Vol 71 Issue 2 pp329-39 
Guichard, S, Kennedy, M, Werzel, E, André C "What promotes fiscal consolidation: OECD country experiences?" OECD Economics Department Working Papers, No 553, OECD Paris

Hannoun H (2010) "Towards a global financial stability framework" $45^{\text {th }}$ SEASEN Governors' Conference, Cambodia, February

Jones, R S and Yoon T (2008) "Enhancing the Productivity of the Service Sector in Japan" Economics Working Paper No 651, OECD, Paris.

Keynes, J M (1930) "The great slump of 1930" in The Collected writings of John Maynard Keynes Vol IX, "Essays in Persuasion" (1972) Macmillan, London

Keynes, J M (1936) "The General Theory of Employment, Interest and Money" Cambridge University Press, Cambridge

Keynes J M (1940) "How to Pay for the War" Macmillan and Co., London

Kindelberger, C P and Aliber, R Z "Manias Panics and Crashes" (Fifth edition) Palgrave Macmillan, New York

Koo, R C (2008) "The Holy Grail of Macroeconomics" John Wiley and Sons, Singapore

Laidler, D (1999) “Fabricating the Keynesian Revolution" Cambridge University Press, Cambridge, UK

Leijonhufvud, A (1968) "On Keynesian economics and the economics of Keynes" Oxford University Press, New York

Leijonhufvud, A (2009) "Out of the corridor: Keynes and the crisis" Cambridge journal of Economics 33, pp741-757

Mankiw G (2006) “The Macroeconomist as Scientist and Engineer" NBER Working Paper 12349, June McCloskey, D (1985) "The Rhetoric of Economics" University of Wisconson Press, Madison, Wisconson

Minsky, H (1992) "the Financial Instability Hypothesis" Jerome Levy Economics Institute WP 74, May

Nakamae T (2010) "How Japan could lead the way back to durable growth" Financial Times 30 March , page 26

Peek, J and Rosengren E S (2003) “Perverse Incentives and the Misallocation of Credit in Japan" NBER Working Paper 9643, Cambridge ME, April

Powell, J (2003) “FDR's Follies" Random House, New York

Rajan R (2005) "Has financial development made the world riskier?" Symposium sponsored by the Federal Reserve Bank of Kansas City, Jackson Hole, Wyoming, August 25-27

Ramsden, J and Kervalishvili P J (2008) "Complexity and Security" Vol 37 NATO Science for peace and security series, April 
Reinhardt, C M and Rogoff K S (2008)"This Time is Different: A Panoramic View of Eight Centuries of Financial Crises" NBER Working Paper Series, NBER, Cambridge Mass.

Rudd, and Whelan, K (2005) "Modelling Inflation Dynamics: A Critical Survey of Recent Research" Prepared for the FRB/JMCB Conference on "Quantitative Evidence on Price Determination" Washngton, September

Schularik, M and Taylor A M (2009) "Credit Booms Gone Bust: Monetary Policy, Leverage Cycles and Financial Crises, 1870-2008" NBER Working paper Series, 15512, NBER, Cambridge, Mass.

Schumpeter, J A (1934) "Depressions: can we learn from past experience?" in "Economics of the Recovery Program"

Smiley G (2002) “Rethinking the Great Depression” Ivan R Dee, Chicago

Soros, G (2009) “Four Lectures” Central European University, Budapest, October

White W R (2004) “Are changes in financial structure extending safety nets?" BIS Working Paper 250, January, Basel

White W R (2005) "Procyclicality in the Financial System: do we need a new macrofinancial stabilisation framework?" Kiel Economic Policy Papers, 2, September

White, W R (2006) “Is Price Stability Enough?” BIS Working Paper 205, April, Basel

White, W R (2008) "Globalisation and the Determinants of Domestic Inflation" BIS Working Paper 250, March, Basel

White, W R (2009) "Should Monetary Policy Lean or Clean?" Federal Reserve Bank of Dallas, Globalisation and Monetary Policy Institute Working paper 34, August, Dallas 